\title{
Classification of Claims and Interests in Chapter 11 and 13 Cases
}

\author{
Stefan A. Riesenfeld $\dagger$
}

Both in reorganization cases under Chapter $11^{1}$ and in debt adjustInent cases under Chapter $13^{2}$ of the Bankruptcy Code the formulation and confirmation of a rehabilitation plan are the central features of the proceedings. Likewise, in both types of rehabilitation cases the classification of claims and the treatinent accorded to each class are essential for the success of the restructuring of the economic affairs of the debtor and the debtor's rescue froin liquidation.

As Chapter 13 is available only to individuals with regular income, the classification will affect only unsecured and, exceptionally, secured claims and will be relatively uncomplicated. Moreover, one of the most common problems-the permissibility of preferential treatinent of unsecured consumer debts guaranteed by an individual other than the debtor-was resolved affirmatively by the Amendments of $1984 .{ }^{3}$ Conversely, the classification problem im Cliapter 11 cases is considerably more coinplex owing to the greater range and variety of the claims ${ }^{4}$ and interests ${ }^{5}$ affected and to the statutory scheme of votes by classes as a prerequisite for confirmation. Although Chapter 11 contains detailed provisions relating to the designation of classes, ${ }^{6}$ the treatment of claims or interests within a class, ${ }^{7}$ and the standards of fairness and equitableness with respect to a class and to relative treatment of senior and jumior classes, ${ }^{8}$ there still exist many doubts as to the amount of flexibility permitted to secure the acceptance of a confirmable plan despite the

$\dagger$ Emanuel S. Heller Professor of Law, Emeritus, Boalt Hall School of Law, University of California, Berkeley. Dr. Jur. 1931, University of Breslau; Dott. in giur. 1934, Umiversity of Milan; LL.B. 1937, Boalt Hall School of Law, Umiversity of California, Berkeley.

1. 11 U.S.C. $\S \S 1101-1146$ (1982 \& Supp. 1985).

2. 11 U.S.C. $\$ \S 1301-1330$ (1982 \& Supp. 1985).

3. 11 U.S.C. $\S 1322$ (b)(1) (1982 \& Supp. 1985), as amended by Pub1. L. 98-353, § 316(1), 98 Stat. 356.

4. "Claim" is defined in 11 U.S.C. $\$ 101(4)$.

5. The Bankruptcy Code does not include a definition of interest. The right of an equity security holder is an interest, as can be seen from $\S 501(\mathrm{a})$ and $\S 101(15)$, but the legislative history supports the conclusion that any ownership interest is an interest for purposes of Chapter 11 . See 3 W. Norton, BankRuptCy LAW AND Practice $\S 59.05$ (1981).

6. 11 U.S.C. $\S \S 1122(a)-(b), 1123(a)(1)$.

7. 11 U.S.C. $\& 1123($ a)(2)-(4).

8. 11 U.S.C. $\S 1129(\mathrm{~b})(2)$. 
objection of one or more impaired classes. ${ }^{9}$ It is the purpose of this paper to discuss some of the problems which have arisen in adjudicated cases and to suggest some criteria for their proper solution, so that the good ship Rehabilitation may avoid the Scylla of overrigidity and the Charybdis of unfairness.

\section{Classification UNDER ChaPTer 11}

\section{A. Background}

A plan of reorganization will be approved by the court if the impairment of the classes of claims and interests provided in the plan restores the viability of the enterprise ${ }^{10}$ (unless the plan itself contemplates its hquidation), ${ }^{11}$ coinplies with the requisite standards of fairness, and is accepted by at least one impaired class of claims. ${ }^{12}$

Since the impairment of secured claims is subject to significant limitations, ${ }^{13}$ the permissibility of the formation of more than one class of unsecured claims and of a different treatinent of such classes is the principal context in which the problein discussed in this study arises.

William L. Norton, author of a widely used and respected treatise on bankruptcy law and practice, advanced the view that under the Code, apart froin the specially authorized separate class of small claims, ${ }^{14}$ "[u]nsecured claims will, generally speaking, comprise one class, whether trade, tort, publicly held debt or a deficiency of a secured creditor."15 Norton found support for his thesis in the fact that under Chapter $\mathrm{X}$ of the Bankruptcy Act, classification of creditors and stockholders was to be fixed "according to the nature of their respective clains and stock"16 and that the Commission on the Bankruptcy Laws of the United States proposed a provision mandating the inclusion of claims of substantially similar character in the same class, except for the creation of a separate

9. 11 U.S.C. $\S 1129(a)(8)$ predicates confirmation of the plan upon acceptance by all "impaired" classes of claims or interests. However, $\S 1129(b)(1)$ permits a cram-down of a plan if at least one impaired class of claims under the plan accepts the plan (as required by $\S 1129(\mathrm{a})(10)$ ), and "the plan does not discriminate unfairly, and is fair and equitable, with respect to each class of claims or interests that is impaired under, and has not accepted, the plan."

10. 11 U.S.C. $\$ 1129($ a)(11).

11. 11 U.S.C. $\$ 1123(b)(4)$ authorizes so-called "liquidation plans."

12. 11 U.S.C. $\S 1129(\mathrm{a})(10)$.

13. 11 U.S.C. \& $1129(b)(2)(A)(i)$-(iii).

14. 11 U.S.C. $\$ 1122(b)$.

15. 3 W. NoRTON, supra note 5 , at $\S 60.05$.

16. 1898 Bankruptcy Act $\S 197$. The phrase was construed to focus on "the legal character or the quality of the claim as it relates to the assets of the debtor." In re Los Angeles Land \& Invs., Ltd., 282 F. Supp. 448, 453 (D. Hawaii 1968), affd, 447 F.2d 1366 (9th Cir. 1971). 
class of small claims for administrative purposes. ${ }^{17}$ However, neither the case law under Chapter X of the Bankruptcy Act nor the legislative history of the Code (or its final language) compels the asserted conclusion. ${ }^{18}$ The 1986 Annual Cumulative Supplement to Norton's commentary concedes that the legislative history is arguably ambiguous ${ }^{19}$ and reiterates the former position primarily because of the argumentum e contrario based on the special exception in 11 U.S.C. section $1122(\mathrm{~b})^{20}$ and the need to prevent classification solely for vote-gathering purposes. ${ }^{21}$

In 1983, discussing the classification problem in the Umited States as compared with the system proposed by the German Kommission for Insolvenzrecht, ${ }^{22} \mathrm{I}$ took the position that neither the language of the Code nor convincing policy considerations required the single class system for unsecured claims and that successful reorganization in many situations required more than one class of unsecured claims.. ${ }^{23}$ Meanwhile, a further imvestigator of the problem has shared the views of the author. ${ }^{24}$

\section{B. Case Law}

Initially the bankruptcy and district courts disagreed on the proper interpretation of the classification rules governing reorganization under Chapter 11 of the Code. Section 1122(a) provides: "Except as provided in subsection (b) of this section a plan may place a claim or imterest in a particular class only if such claim or interest is substantially similar to the other claims or interests of such class."25

In other words, section 1122(a) restricts the inclusion within a class to substantially similar claims or interests, but does not mandate such inclusion. Such a requirement would have to be derived from other considerations or provisions. ${ }^{26}$ Of course, inclusion within a class necessitates equal treatment. ${ }^{27}$

17. REPORT OF THE COMMISSION ON THE BANKRUPTCY LAWS OF THE UNITED STATES, H.R. Doc. No. 137, 93rd Cong., 1st Sess. 241 (1973) (pg. II).

18. See Blair, Classification of Unsecured Claims in Chapter 11 Reorganization, 58 AM. BANKR. L.J. 197, 211-17 (1984).

19. 3 W. NoRToN, supra note 5 , at $\S 60.02$ (Supp. 1986).

20. Id.

21. Id. at $\$ 60.05$.

22. Riesenfeld, Das amerikanische Sanierungsverfahren, Ein rechtsvergleichender Oberblick, 44 KONKURS-TREUHAND-UND SCHIEDSGERICHTSWESEN 85, 93 (1983).

23. Id. at 93.

24. Blair, supra note 18; accord Anderson, Classification of Claims and Interests in Reorganization Cases Under the New Bankruptcy Code, 58 AM. BANKR. L.J. 99, 119 (1984).

25. 11 U.S.C. $\$ 1122(a)$.

26. The argument that $\S 1122$ (a) also mandates the converse is usually based on $\S 1122(b)$, while the opposite argument is based on the language of $\$ 1322(\mathrm{~b})(1)$ which speaks of the designation of a class or classes of unsecured claims "as provided in section 1122."

27. 11 U.S.C. $\S 1123(4)$. 
The leading cases seemingly following (former) Judge Norton's view that unsecured claims will coinpose one class are In re Pine Lake Village Apartment Co., ${ }^{28}$ In re Mastercraft Record Plating, Inc., ${ }^{29}$ In re $S \& W$ Enterprise, ${ }^{30}$ and In re Fantastic Homes Enterprises, Inc. ${ }^{31}$ The opposite view is represented by In re Huckabee Auto Co., ${ }^{32}$ In re U.S. Truck Co., Inc., ${ }^{33}$ In re Planes, ${ }^{34}$ In re Rochem, ${ }^{35}$ and In re AOV Industries, Inc. ${ }^{36}$ An analysis of the cases, however, seems to show that the difference of opimion, in the light of the facts of the cases, is not as great as inay appear at first blusli.

In Pine Lake Village Apartment Co., ${ }^{37}$ the issue of the confirmability of a plan of reorganization arose on a inotion by a inortgagee for relief froin the automatic stay im a Cliapter 11 case. According to section 362 (d)(2), rehef from the stay on such a motion must be granted "if the debtor does not liave an equity in the encumbered property and such property is not necessary to an effective reorganization," 38 that is, if the court finds that there are no prospects for a confirmable plan. In that case the debtor was a limited partnership whose only asset consisted of a multiapartment house complex valued at approximately $\$ 6,400,000$. The property was subject to a first mortgage of approximately $\$ 14,000,000$, including principal and arrears of interest. The only otlier creditors were trade creditors whose claims aggregated approximately $\$ 45,000$.

The debtor's only general partner was a corporation. At the time of the inotion for relief from the automatic stay, the debtor subinitted a plan of reorganization separately classifying creditors and interest holders into four classes. The first class embraced wage claims. The second class included the claims of the mortgagee. The third class consisted of the trade creditors, and the fourth class comprised the interest of the general and limited partners of the debtor. The plan provided for full payment in cash on the effective date of the plan to the class one and class three creditors. The plan further provided that the inortgagee receive $\$ 350,000$ in cash on the effective date of the plan and on its remaining allowed claims of $\$ 13,500,000$, a note for the balance plus interest in monthly installments cominencing one inonth after the effective date of

\footnotetext{
28. 19 Bankr. 819 (Bankr. S.D.N.Y. 1982).

29. 32 Bankr. 106 (Bankr. S.D.N.Y. 1983).

30. 37 Bankr. 153 (Bankr. N.D. III. 1984).

31. 44 Bankr. 999 (M.D. Fla. 1984).

32. 33 Bankr. 132 (Bankr. M.D. Ga. 1981).

33. 47 Bankr. 932 (E.D. Mich. 1985), aff'd sub nom., In re U.S. Truck Co., Inc., 800 F.2d 581 (6th Cir. 1986).

34. 48 Bankr. 698 (Bankr. N.D. Ga. 1985).

35. 58 Bankr. 641 (Bankr. D. N.J. 1985).

36. 792 F.2d 1140 (D.C. Cir. 1986).

37. In re Pine Lake Village Apartment Co., 19 Bankr. 819 (Bankr. S.D.N.Y. 1983).

38. 11 U.S.C. $\S 362$ (d)(2).
} 
the plan and, continuing for thirty years. Finally, the plan proposed that the interests of the general and limited partners remain unimpaired but that the equity security holders of the debtor contribute $\$ 700,000$ in cash to enable the debtor to inake the payments required under the plan and to permit repairs and rehabilitation of the subject premises.

Judge Schwartzberg granted the inotion for rehef froin the stay, holding that the plan in its present form or if anended as suggested was not confirmable because the mortgagee had announced rejection of any plan. ${ }^{39}$

Leaving aside the issue of relief from the stay under section 362(d)(1), the court rested its decision on the absence of a likelihood of reorganization. Under the plan as proposed, only class two (consisting of the mortgage) was mipaired. As a resnlt the plan was not confirmable under either section $1129(\mathrm{a})^{40}$ or section $1129(\mathrm{~b}) .^{41}$ Therefore the opinion considered the possibility that the debtor might "amend its plan so as to mipair the rights of the trade creditors, such as by offering less than full payment on confirmation, or by providing for full payinent over an extended period of time" and that the trade creditors wonld still accept the plan. ${ }^{42}$ Yet it concluded that the plan still wonld not be confirmable by cram-down.

The court gave several reasons for its holding. The first was the position that the plan impermissibly lumped the mortgagee's secured claim and the unsecured claim together in one class ${ }^{43}$ and, likewise if amended as suggested, impermissibly divided the deficiency claim of the mortgagee and the unsecured claims of the trade creditors into separate classes. The second reason was based on the finding that the net income froin the property was "woefully less" than the proposed payments under the note. ${ }^{44}$ The third reason, finally, was Judge Schwartzberg's view that the retention by the general partner and the limited partners of their interest in the property violated section $1129(\mathrm{~b})(2)(B)(\mathrm{i})$ and section 1129 (b)(2)(B)(ii). ${ }^{45}$

Actually, the second reason wonld have sufficed to render the proposed plan 11onconfirmable pursuant to section 1129(a)(11). The third reason is inore questionable because the judge lost sight of the proposed payment of $\$ 700,000$ in return for the retention of the ownership interests. The most debatable reason, however, is the first one because it was predicated on the idea that, absent acceptance by all claimholders, no

39. Pine Lake Village Apartment Co., 19 Bankr. at 833-34.

40. $\S 1129(a)(8)$ requires acceptance by all impaired classes.

41. $\S 1129(\mathrm{~b})$ requires acceptance by at least one impaired class.

42. Pine Lake Village Apartment Co., 19 Bankr. at 829.

43. Id. at 832 .

44. Id.

45. Id. at $832-33$. 
plan would have been confirmable that placed the deficiency claim holders and the trade creditors im separate classes with different treatment. According to the court,

The debtor may not ignore the rejection of its plan by the holder of a large unsecured deficiency claim simply because the debtor designated a specially preferred separate class of easily created trade creditors whose acceptances may be readily obtainable by offering them more than the disfavored deficiency claim holder. ${ }^{46}$

In the court's view, "Manifestly such treatment of unsecured claims is unfairly discriminatory within the meaning of 11 U.S.C. section 1129(b)(1)."47 It can hardly be said, however, that any different treatment is per se discriminatory. Moreover, even better treatment may not necessarily be unfairly discriminatory, if the relations between the parties and their continuation to facilitate reorganization call for differential treatment.

The other cases following Norton's thesis present much simpler facts. In Mastercraft Record Plating, Inc., ${ }^{48}$ the court was confronted with a plan dividing the general unsecured claims into three impaired classes: claims under $\$ 20,000$, claims over $\$ 20,000$, and disputed claims. The plan treated the first two classes identically, made no provision for the treatinent of disputed claims, and failed to include a class specifymg the treatment of stockholders. Although the Creditors' Committee moved to affirm the plan, the court held that it could not confirm the plan until the status of the contested claims was determined and the defective classification remedied. ${ }^{49}$ Obviously the classification of the undisputed claims was irrational, although the court failed to explain how it affected the acceptance.

In re $S \& W$ Enterprise $^{50}$ is another exainple of unnecessary judgemade confusion. In that case two unsecured creditors held claims in the amount of $\$ 450$ and $\$ 421.08$ respectively. A third creditor held a claim of $\$ 654,940$ secured by collateral valued at $\$ 200,000$. The reorgamization plan provided for three classes of claims: one for the secured portion of the major creditor's claim, one for the creditors with the clains under $\$ 1000$, and one for the unsecured portion, amounting to $\$ 454,940$, of the major creditor. The plan proposed payinent of the sinall claims in full within thirty days of confirmation and payinent of the unsecured portion of the claim of the major creditor only after payment in full of the secured claim and, even in that event, over an extended period of time. The major creditor objected to the confirmation. The bankruptcy judge

\footnotetext{
46. Id. at 831 .

47. Id.

48. 32 Bankr. 106 (Bankr. S.D.N.Y. 1983).

49. Id. at 108.

50. 37 Bankr. 153 (Bankr. N.D.N.Y. 1984).
} 
demied confirmation after noting that the impairment of the major creditor's claim was not at issue and that the debtor had not requested a cramdown. ${ }^{51}$ The court based its denial solely on the ground that section 1122(b) did not apply in the case and that therefore the formation of two classes for three unsecured claims was impermissible. ${ }^{52}$ Unfortunately, the court overlooked that under its analysis, the objection of one class barred the confirmation in the absence of a request for cram-down and that even if the classification was permissible, the result would have been the same. Even if there had been a request for cram-down the result would have been the same provided that the two small claims remamed unimpaired.

The last case relying on the purported single class system for unsecured debts is In re Fantastic Homes Enterprises, Inc. ${ }^{53}$ In that case, the plan created four classes of unsecured claims providing dissimilar treatment based merely on the dollar amount of each category. The result was that a claim shightly in excess of $\$ 100,000$ received less than a claim of the same nature shightly under $\$ 100,000$. Obviously such division was, as the judge found, unfair and unwarranted. ${ }^{54}$

In contrast to the cases discussed so far, other courts have rejected the unitary class rule. The first case to take this approach was In re Huckabee Auto Co. ${ }^{55}$ In that case GMAC was the holder of a claim of $\$ 100,346.07$, designated in the plan as Subordinated Secured Debt. The debt resulted from a postpetition settlement of prepetition claims, involving GMAC, the debtor, and a bank. The settlement provided that GMAC was entitled to the same payments on the debt as the other unsecured creditors, but that payment of the balance was secured by specified collateral that also secured other claims of GMAC. The settlement was to be part of the reorganization plan without modification.

The plan formed a class (designated Class 2) for all secured claims of GMAC, listing also the Subordimated Secured Debt. In addition, the claim was also placed into a class (designated Class 7) for all unsecured creditors of the debtor. That class was to receive twenty percent on the allowed claims payable in five equal armual imstallments. The Creditors' Committee objected to confirmation on the ground that the participation of a Class 2 claimant in Class 7 was inappropriate. The inclusion of the $\$ 100,346.07$ in Class 2 resulted in the acceptance of the plan by that class, although without that enlargenent the class would have rejected

51. Id. at 156 .

52. Id. at $158-59$.

53. 44 Bankr. 999 (Bankr. M.D. Fla. 1984).

54. Id. at 1001.

55. 33 Bankr. 132 (Bankr. M.D. Ga. 1981) (“Huckabee I'). 
the plan and thus barred the confirmation of the plan under section 1129(a).

The court noted that section 1122 does not require the inclusion of claims within classes but provides only that all claims placed within a class must be substantially similar. ${ }^{56}$ The court held that inclusion of the $\$ 100,346.07$ claim in Class 2 was consistent with its secured status but that its simnltaneous inclusion in Class 7 violated both the "substantially similar" requirement of section 1122(a) and the "saine treatment" requirement of section $1123(\mathrm{a})(4) .{ }^{57}$ Additionally, the court noted that the $\$ 100,346.07$ claim was unimpaired, while the other claims were impaired. ${ }^{58}$ Actually it is open to doubt whether the twenty percent of the GMAC claim in issue belonged in either of the two classes, because it was to be paid in full and was to that extent treated as unsecured. However, its total inclusion in Class 2 was harmless, since Class 2 included only claims of GMAC.

Much more cogent authorities for the rejection of the "no-morethan-one-class for impaired unsecured claims" rule are the three opimons relating to the confirmation of the reorganization plan in In re U.S. Truck Co., Inc. ${ }^{59}$ The earhiest amended reorganization plan proposed in that case that was the subject of a pubhished decision came before a bankruptcy judge for the Eastern District of Michigan in $1984 .^{60}$ The plan in question placed all unsecured prepetition habilities of the debtor exceeding $\$ 200$, including workers' compensation liability as self-insurer, into one class and provided payment of fifty-five percent of the allowed amount. The court held tliat inclusion of the workers' compensation claims in the same class with unsecured claims of trade creditors was neither required nor permitted in view of the special character of the former claims under applicable state law, and that therefore the plan as proposed could not be confirmed. After quoting the views advanced in the commentary by Norton and the cases relying thereon, the bankruptcy court strongly criticized the thesis that "all unsecured claims are equal" as "simplistic and mischievous," 61 as demonstrated by the instant case.

A further amended plan proposed by the debtor was scrutinized and confirmed by the U.S. district court in a 1985 decision $^{62}$ which was

56. Id. at 137. The court specifically overruled the objection based on misclassification.

57. 33 Bankr. 141, 148 (Bankr. M.D. Ga. 1981) ("Huckabee Ir").

58. Id. at 147 n.3.

59. 42 Bankr. 790 (Bankr. E.D. Mich. 1984); In re Planes, 47 Bankr. 932 (E.D. Mich. 1985), aff'd sub nom., In re U.S. Truck Co., Inc., 800 F.2d 581 (6th Cir. 1986).

60. 42 Bankr. 790 (Bankr. E.D. Mich. 1984).

61. Id. at 795 .

62. 47 Bankr. 932 (E.D. Mich. 1985). The reference to the Bankruptcy Court was withdrawn because of jurisdictional considerations. The bankruptcy judge in charge of the case resigned. 
affirmed on appeal. ${ }^{63}$ This new plan ${ }^{64}$ classified the workers' compensation claims in a separate and unimpaired class, but a new controversy arose concerning the proper classification of unsecured claims for damages arising from the rejection of a collective bargaining agreement. The plan provided three classes for unsecured claims: Class IX, consisting of disputed unsecured claims for damages $(\$ 5,000,000)$ allegedly resulting from the rejection of the collective bargaining agreement, Class $X$ for unsecured claims of $\$ 200$ or less, and Class XI, comprising unsecured claims in excess of $\$ 200$ including those arising from the rejection of other executory contracts. Classes IX and XI were impaired. Class IX was to receive the same treatment as Class XI to the extent that the claim was allowed by the court.

The district court confirmed the plan over the objection of Class IX, the sole dissenting class. Judge Pratt quoted with approval the bankruptcy judge's statement in the prior phase of the case characterizing the tenet that unsecured claims belong in the same class as simplistic and imischievous and discussed at length the features that rendered the separate classification of the rejection claims to be in complance with section $1129(b)(1){ }^{65}$ The court did not ignore that inclusion of the rejection claims estimated at $\$ 2,000,000$ pursuant to section 502 (c) in the class with the other unsecured claims would have converted that class from an accepting to a rejecting class, but it concluded that the divergent interests of the umion and the other creditors, as well as the particular continued negotiability of these claims in future bargaining, justified separate classification. ${ }^{66}$ Moreover, the assent of Class XI was not needed for a cramdown, since the plan provided two other impaired classes that had assented. ${ }^{67}$ The court also ruled that the treatment of the equity securities holder did not contravene section 1129(b)(2)(B)(ii) since the issuance of new stock for a capital contribution of $\$ 100,000$ complied with the substantiality standard developed by the case law. ${ }^{68}$

Judge Pratt's judgment was affirmed on appeal. ${ }^{69}$ Judge Kermedy, writimg for the panel, held that the legislative history as well as pre-Code cases seemed to support the conclusion "that Congress no longer intended to impose the now-omitted requirement that similar claims be

63. In re U.S. Truck Co., Inc. 800 F.2d 581 (6th Cir. 1980).

64. The text of the plan is published as an appendix to the District Court's decision. U.S. Truck Co., 47 Bankr. at 944-52.

65. Id. at 938.

66. Id.

67. Id. at 940 . The court referred to Classes VI and VII. Class VII was specifically designated as impaired; Class VI was not, but $\$ 1123(\mathrm{a})(3)$ requires only the specification of the treatment of an impaired class and not the designation of a class as impaired.

68. Id. at 941 .

69. In re U.S. Truck Co., Inc., 800 F.2d 581 (6th Cir. 1986). 
classified together."70 While the court emphasized that segregation of similar claims must be subject to some limits, it rejected the position that the motive of forming an assenting class was per se a reason to deny confirmation. ${ }^{71}$ The court agreed with the court below that the Teamsters Committee had a "noncreditor" interest which dictated its vote. ${ }^{72}$ Therefore refusal to permit separate classification would allow the Committee to prevent a court from considering a plan that a significant group of creditors with similar imterests accepted. ${ }^{73}$ The court likewise sustained as not clearly erroneous the findings of the court below that the capital contribution of the former equity securities holder in return for new stock was "substantial and essential."74

Although the rejection of the one-class gospel on the circuit level is, of course, the most authoritative precedent, it is useful to discuss two remaining bankruptcy court decisions.

In re Planes, Inc. ${ }^{75}$ involved the confirmation of a plan which segregated the unsecured claims into disputed, contingent, and unliquidated claims (Class XIII), allowed general unsecured claims (Class XIV), and claims held by the principal stockholder of Planes and his wife (Class XVI). In addition, a particular class was formed for a Class VIII claimant, an undersecured creditor, whose claim had not been allowed as partly secured and partly unsecured. While four impaired classes accepted the plan, Class VIII and Class XIV rejected it. The claimants in Class VIII and XIV were not entitled to vote or receive distribution on their contingent deficiency or unliquidated claims until estimated by the court. The judge held that "the existence of several classes of unsecured claims in the case sub judice does not provide a sufficient basis for rejecting the Plan without further inquiry,"76 but that the failure to reduce all unsecured claims to dollar amounts pursuant to sections 502(c) and 506(a) prevented confirmation at that time. ${ }^{77}$ The court also found that the treatment of the secured portion of the claim in Class VIII violated the requirements of section $1129(\mathrm{~b})(2)(\mathrm{A})^{78}$ and that the preferential treatment of the unsecured claims of a former shareholder was prima facie unfairly discriminatory, unless justified at a subsequent evidentiary hearing. ${ }^{79}$

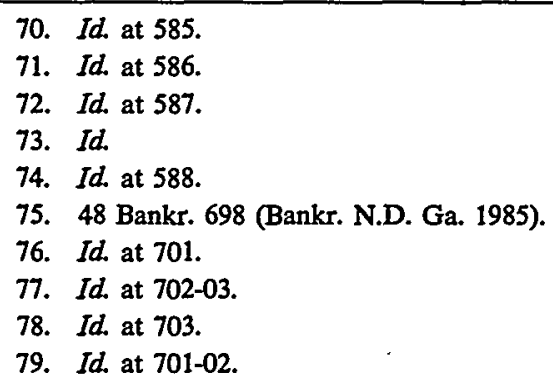


In In re Rochem, ${ }^{80}$ the proposed modified plan provided for seven classes of creditors of which one (Class Three) consisted of tort claimants, while another (Class Four) included all other general unsecured claims-trade creditors and law firms. The principal claim in Class Three consisted of unliquidated and disputed tort claims in the amount of $\$ 35,000,000$, while the claims of the Class Four creditors totalled $\$ 171,130.00$. The plan proposed a fifty percent dividend to the Class Four creditors payable over a period of thirty-six months, while the principal tort claim holder was to receive a $\$ 50,000$ lump sum payment within 180 days after confirmation. The court, relying on Huckabee Auto $\mathrm{Co}^{81}$ as well as cases decided under Chapter 13, held that a separate classification of trade creditors and tort creditors was not per se prohibited by section 1122(a) of the Code and that preferential treatment accorded to trade creditors, as coinpared with that given to the holder of a inajor unliquidated tort claim, was not necessarily unfairly discriminatory. ${ }^{82}$ The court confirmed the proposed plan without atteinpting to estimate the tort claim as required by section 502(c), relyimg on tests for unfair discrimination developed under Chapter $13 .{ }^{83}$

Based upon the holdings and facts in the cases analyzed above, it would seein that the advocates of the "one-class-for-all unsecuredclaims" doctrine are false prophets and that inultiple classes for unsecured claims are permissible and nay be called for in appropriate circuinstances. The fact that the forination of one assenting class inay be a factor in the proposed classification scheine is not sufficient to find a violation of the policies of the Code, so long as the classes are treated differently and such difference in treatınent is not unfairly discriminatory. Even when the separate classes are treated substantially alike, a segregation inay be possible if the claimants in one class are motivated by what the Sixth Circuit has called "non-creditor interests." line between fair and unfair discrimination is hard to draw. The lodestar is the policy to further rather than to hamper rehabilitation.

The conclusions set forth above are buttressed by a decision on the circuit court level dealing with the converse situation: creation of a umtary class for all unsecured creditors but subjection of soine ineinbers in

80. 58 Bankr. 641 (Bankr. N.J. 1985).

81. 33 Bankr. 132 (Bankr. M.D. Ga. 1981); see supra text accompanying notes 55-57.

82. Rochem, 58 Bankr. at $642-44$.

83. Id. at 643 . The court saw an advantage given to the tort claimant in that the payment was guaranteed by the debtor's president and payable without dependency upon the continued existence and profitability of the debtor. The court reasoned that the tort claim's inclusion in Class Four would increase the allowed claims in that class to approximately $\$ 17,671,130.00$. That, however, would be true only if $50 \%$ of the tort claim were allowed, a totally unsubstantiated assumption.

84. In re U.S. Truck Co., Inc., 800 F.2d 581, 587 (6th Cir. 1986). 
that class to more burdensome conditions for pay-outs. ${ }^{85}$ The debtor in that case was a U.S. corporation engaged in the export of coal. Its exclusive sales agent for Europe was a German company (Steag). After the debtor filed a petition under Chapter 11, it commenced an action against Steag, claiming that the two companies had engaged in a joint venture relationship. In addition, one of the principal creditors (Hawley Fuel Coal, Inc.) filed suit against Steag based upon a purported separate guaranty of the payment of coal dehivered to the debtor. A reorganization plan was worked out proposing placement of all unsecured creditors in one class and providing for a percentage payment of their claims with funds partly derived from assets of the debtor and partly contributed by Steag. The overwhelming majority of the creditors accepted the plan, but Hawley rejected it, contending that the required release of its special guarantee violated sections $1122(a)$ and 1123(a)(4) of the Code. The district court rejected the objections and confirmed the plan. ${ }^{86}$ The court of appeals held that while the plan did not violate section 1122(a), it did contravene section 1123(a)(4) because the required relinquishment of the rights under the purported special guarantee was inore burdensome than the release of the merely derivative rights claimed by the majority of the creditors. The court did not overturn the confirmation but modified the plan by striking the condition of the release of rights under special guarantees as a condition of participation. The court held that the inclusion of claims secured by guarantees of third parties and claims not so secured in the same class did not violate the rule restricting class membership to "substantially similar" claims, but that once so included, all clains were entitled to the same treatment. The court indicated specifically that section 1123(a)(4) barred the proposed treatment of Hawley only because it was imposed by the plan "after failing to place [Hawley] in a separate category, as it might have under section 1122(a)." 87

The description of secured claims and ownership interests is much less troublesome than that of unsecured claims. "Secured creditors with liens in different property or liens in the same property but with different priorities may not be classified together since their legal rights are not substantially similar."88 Exceptions would consist chiefly of security interests held as tenants in common or other forms of co-ownership. ${ }^{89}$

Ownership interests, whether consisting of equity securities in the case of corporate debtors or of legal or equitable property rights other than hens or encumbrances in the case of individual debtors, must be

\footnotetext{
85. In re AOV Industries, Inc., 792 F.2d 1140 (D.C. Cir. 1986).

86. Id.

87. Id.

88. In re Holthoff, 58 Bankr. 216, 219 (Bankr. E.D. Ark. 1985) (citation omitted).

89. Cf. In re Commercial W. Fin. Corp., 761 F.2d 1329 (9th Cir. 1985).
} 
included in at least one class in the plan..$^{90}$ In the case of corporate stockholders, compliance with sections $1123(a)(4)$ and 1123(b)(4) will usually present few problems. There are, lowever, situations where classification problems may emerge. A good illustration is furnislied by In re Acequia, Inc. ${ }^{91}$ In that case one-half of the stock in the debtor was owned by an ex-liusband (Clinton), and the other half by his ex-wife (Haley). The relationship of the former spouses was acrimonious and resulted in a court-approved settlement, pursuant to which Clinton executed an irrevocable proxy to Haley, granting ler the right to manage the debtor for two and one-half years. The plan of reorganization, whicl was a socalled liquidation plan, contained detailed management provisions governing the period of the pendency of the plan. Haley was vested with the management of the debtor but all slareliolders were prohibited from removing directors. The plan classified all shareholders in the same class and specified that the shareholders' interests were not impaired. Clinton contended that his rights were impaired and that the plan was contrary to law. The court held that a plan could inodify shareholders' riglits, that the placennent of both sliareholders in the same class did not violate section 1122(a), and that vesting the managerial riglits in Haley did constitute unequal treatment as prohibited by section 1123(a)(4) because neither ex-spouse could exercise shareholders' voting rights to elect or remove directors or to alter the board's composition. The court found that although the plan impaired shareholders' rights, it did not discriminate unfairly between the riglits of the feuding ex-spouses.

\section{II Classification Under Chapter 13}

Under Chapter 13 the classification of claims is less complex than under Chapter 11 since there is no vote by classes and the cram-down provisions are not subject to the priority rules governing Cliapter 11 plans.

Section 1322(a)(3) authorizes classification of claims, but mandates the same treatment for each claim within a particular class. Section 1322(b)(1) permits different classes for unsecured claims "as provided in section 1122 of this title" but subject to the limitation that the plan may not discriminate unfairly agamst any class so designated. In turn this limitation is interpreted by the 1984 amendinents as not to exclude special treatinent of claims for consumer debts on which an individual otler than the debtor is a co-obligor.

Actually, the prohibition agamst unfair discrimination between

90. In re Holthoff, 58 Bankr. 216 (Bankr. E.D. Ark. 1985).

91. 787 F.2d 1352 (9th Cir. 1986). 
classes of unsecured claims and the mandate of the same treatment for unsecured claims within the same class are the main standards for classification, although the reference to section 1122 injects the additional requirement that the claims within a class must be "substantially similar." Consequently - apart from the special proviso relating to consumer debts of the debtor on which another individual is liable with the debtor, which authorizes a different treatment for such debts-the general classification rules applying in Chapter 11 cases will also govern Chapter 13 cases. Even prior to 1984 , Barnes v. Whelan ${ }^{92}$ interpreted the reference to section 1122 as not precluding separate classes for cosigned and for other unsecured debts, although the court did not condone unfair discrimination between such classes. ${ }^{93}$ The court held that not every differential treatment was proscribed. "What constitutes fair discrimination will vary from case to case . . . . The court must examine the amounts proposed for each class in light of the debtor's reasons for classification, and exercise sound discretion." 94 On that basis the court refused confirmation of a plan which proposed to pay cosigned claims totalling $\$ 7,000$ in full and only one percent on the remaining unsecured debts totalling $\$ 24,500$. The court, however, did not intimate that payment in full of secured and cosigned debts with no payment provided for the other unsecured debts would in every instance constitute unfair discrimination, and confirmation of such plans has been upheld at the circuit level even prior to the amendments of $1984 . .^{95}$ It would seem that the same principles still govern and that the permitted preferential treatment of consumer debts of the debtor on which another individual is liable with the debtor is not by legislative fiat completely immunized against being considered an unfair discrimination, although ordinarily that would not be the case. ${ }^{96}$ While the statute authorizes "different" treatment, it has been held in In re Dondero, ${ }^{97}$ that only more favorable treatment is permitted. In that case the Chapter 13 debtor was a cosigner on a loan given to his son, and the court overlooked that the statutory proviso applies in terms only to consumer debts of the debtor. Certainly, the narrowness of the proviso should not be read to imply that separate classification and separate treatment may not constitute fair differentiation (in contrast to unfair discrimination) also in other meritorious cases. ${ }^{98}$

92. 689 F.2d 193, 201-02 (D.C. Cir. 1982).

93. Id., accord Public Fin. Corp. v. Freeman, 712 F.2d 219, 221-22 (5th Cir. 1983) (designation of creditors holding cosigned notes and other unsecured creditors as members of separate classes is permissible under $\S 1322(b)(1))$.

94. Barnes, 689 F.2d at 202.

95. See, e.g., Public Finance Corp. v. Freeman, 712 F.2d 219 (5th Cir. 1983).

96. Cf. In re Perkins, 55 Bankr. 422 (Bankr. N.D. Okla. 1985).

97. 58 Bankr. 847 (Bankr. Ark. 1986).

98. In re Harris, 62 Bankr. 391 (Bankr. E.D. Mich. 1986); see also In re Todd, 65 Bankr. 249, 253 (Bankr. N.D. Ill. 1986); In re Gibson, 45 Bankr. 783 (Bankr. N.D. Ga. 1985). 